\title{
The Roles of Key Electrolytes in Balancing Blood Acid-Base and Nutrient in Broiler Chickens Reared under Tropical Conditions
}

Ibukun Olukorede Popoola, Oluwabukola Rashidat Popoola, Matthew Oluwatobi Ojeniyi, Oluwaseyi Olamide Olajide, Eustace Ayemere Iyayi

Department of Animal Science, University of Ibadan, Ibadan, Nigeria

Correspondence to: Ibukun Olukorede Popoola, popoolaibukun@yahoo.com

Keywords: Blood Acid-Base, Monovalent Ions, Broilers, Blood Glucose, Heat Stress, Serum Minerals

Received: December 1, $2019 \quad$ Accepted: December 28, $2019 \quad$ Published: December 31, 2019

Copyright (c) 2020 by author(s) and Scientific Research Publishing Inc.

This work is licensed under the Creative Commons Attribution International License (CC BY 4.0).

http://creativecommons.org/licenses/by/4.0/

\section{Open Access}

\section{ABSTRACT}

The loss of electrolyte balance in diets of broiler chickens has resulted in a serious disturbance of blood acid-base balance, coupled with elevated body temperature. The body losses carbon dioxide $\left(\mathrm{CO}_{2}\right)$ and bicarbonate $\left(\mathrm{HCO}_{3}\right)$, resulting in respiratory alkalosis or acidosis. Under tropical conditions of high environmental temperatures, the balance of electrolytes in feeds must be set much higher as to maintain equal metabolic and digestive efficiency. However, information on the ideal dietary electrolyte balance (DEB) that could effectively correct acid-base imbalance in broiler chickens under severe heat stress condition is scanty. Therefore, the effects of varying electrolyte balance in diets on haematology, blood glucose and serum inorganic elements were assessed in broiler chickens at starter (0 - $21 \mathrm{~d})$ and finisher (22 - $35 \mathrm{~d}$ ) phases, under temperature-humidity index of 24.97 - 35.19. One day-old Arbor Acre chicks $(n=300)$ were procured and randomly allotted to diets supplemented with potassium chloride and sodium bicarbonate, to balance monovalent ions (sodium, potassium and chloride) at 210 (T1), 240 (T2), 270 (T3), 300 (T4), 330 (T5) and 360 (T6) $\mathrm{mEq} / \mathrm{kg} \mathrm{DEB}$, in a completely randomised design. On days 21 and 35 , blood $(5 \mathrm{~mL})$ samples were collected from birds in each replicate whose weights were closest to the mean class weight for haematology and serum biochemical indices using standard procedures. Data were analysed using descriptive statistics and ANOVA at $\alpha=0.05$. Different levels of DEB did not significantly affect $(P>0.05)$ haematology and blood glucose at starter phase. However, at finisher phase, heterophil: lymphocyte of birds on 270 and $240 \mathrm{mEq} / \mathrm{kg}$ DEB were lower $(\mathrm{P}<0.05)$ compared to other dietary treatments. Blood acid-base balance was relatively enhanced in birds on aggregate DEB level of $360 \mathrm{mEq} / \mathrm{kg}$ with reduced chloride ion 
and relatively lower incidence of hemodilution with respect to high haemoglobin levels as this level is advantageous in balancing blood acid to base ratio in broiler chickens reared under severe environmental temperatures higher than $43^{\circ} \mathrm{C} \pm 5^{\circ} \mathrm{C}$ as against some previous opinions that did not take into consideration, the inherent dietary electrolyte balance in feedstuff, other functional mono or divalent ions, and the severity of environmental factors.

\section{INTRODUCTION}

According to [1], the adverse effects of high environmental temperature and imbalance of electrolytes in feeds and blood have resulted in respiratory alkalosis, decreased feed intake and growth performance in broiler chickens. Respiratory alkalosis occurs when carbon dioxide and oxygen balance in the blood are not kept at equilibrium. During respiration, the lungs exhale carbon dioxide and inhales oxygen, but when stress occur, the birds breathe faster, dropping the levels of carbon dioxide and causing a sharp rise in blood $\mathrm{pH}$, and causing a rise in blood alkalinity. Some of the physical defects of respiratory alkalosis include discomfort in the chest area, decreased feed intake and muscle spasms, among others. [2] reared broilers under moderately high ambient temperatures and relative humidity and reported significantly high blood $\mathrm{pH}$ and bicarbonate $\left(\mathrm{HCO}_{3}\right)$ concentration with $\mathrm{DEB}$ of $360 \mathrm{mEq} / \mathrm{kg}$ compared to 0,120 and $240 \mathrm{mEq} / \mathrm{kg}$ at $42 \mathrm{~d}$ of age. The authors noted further that the base excess value was closest to zero $(-0.30)$ in the heat stress room with $240 \mathrm{mEq} / \mathrm{kg}$ DEB. [3] opined that the blood base excess value near to zero is desirable, as it indicates the maintenance of required acid-base balance for better performance. [4] stated that an increase in plasma chloride ion decreases hydrogen ion excretion and bicarbonate ion reabsorption by the kidneys, while an increase in plasma sodium ion increases hydrogen ion excretion and bicarbonate ion reabsorption and noted that both situations affect blood $\mathrm{pH}$ differently. Also an increase in plasma potassium ion decreases bicarbonate ion reabsorption from the kidneys. Higher levels of dietary chloride depress blood $\mathrm{pH}$ and bicarbonate and are associated with the occurrence of tibial dyschondroplasia and cartilage abnormalities and competitive assimilation of calcium in the small intestine [5].

Birds on $250 \mathrm{mEq} / \mathrm{kg}$ showed better performance, well maintained blood $\mathrm{pH}$, bicarbonate, hemoglobin, heterophil $(\mathrm{H})$, lymphocytes $(\mathrm{L}), \mathrm{H}$ to $\mathrm{L}$ ratio and blood nutrients (glucose, $\mathrm{Na}, \mathrm{K}$ and $\mathrm{Cl}$ ) while retaining more monovalent ions $(\mathrm{Na}, \mathrm{K}$ and $\mathrm{Cl})$ [3]. It has been well established that severe heat stress, that induces panting, results in the loss of carbon dioxide $\left(\mathrm{CO}_{2}\right)$, reduction in blood partial pressure of $\mathrm{CO}_{2}$ $\left(\mathrm{pCO}_{2}\right)$, high blood $\mathrm{pH}$, and loss of $\mathrm{HCO}_{3}$ and cations, particularly potassium ion $\left(\mathrm{K}^{+}\right)$in urine. Any therapy that replenishes either lost carbon dioxide, $\mathrm{HCO}_{3}$, mineral ions and reduces the alkalotic $\mathrm{pH}$ to maintain the blood acid-base balance will be considered as beneficial. During heat stress, increase in heterophils and decrease in lymphocytes along with an increase in $\mathrm{H}$ to $\mathrm{L}$ ratios have been well noted [6-8]. [9] noted higher blood glucose in heat stressed broiler chickens, while [10] reported lower values of blood haematocrit in heat-stressed birds. Lower haemoglobin concentration was also observed in heat stressed broilers [7, 11]. As ambient temperature rises, the blood potassium ion and sodium ion concentration decreases, while chloride ion increases resulting in low blood electrolyte balance [12]. However, [13] did not observed any significant effect of varying DEB treatments on blood electrolytes, blood glucose and physiological parameters in heat stressed broilers. The authors opined that during heat stress, broiler chickens made use of compensatory mechanisms when attempting to maintain acid-base homeostasis, blood nutrient and physiological variable concentrations. Therefore, the continual exposure to high temperatures probably promotes adaptive responses, thus making the interpretation of the analyzed blood component variables more difficult [13]. At higher environmental temperatures, the balance of dietary electrolytes must be set much higher as to maintain equal metabolic and digestive efficiency. However, information on the ideal dietary electrolyte balance that could effectively correct acid-base imbalance in broiler chickens under severe heat stress condition is scanty. Therefore, the objective of this study was to examine the role of key monovalent minerals on haematology, blood nutrient and serum inorganic elements of broiler chickens reared under high ambient temperatures. 


\section{MATERIALS AND METHODS}

The protocol for these experiments were reviewed and approved by the Institutional Animal Care and Use Committee; and the Agricultural Biochemistry and Nutrition Unit of the Department of Animal Science, University of Ibadan, Nigeria. The study was carried out at the Teaching and Research Farm, University of Ibadan, Nigeria. A total of 300, one-day old Arbor Acre broiler chicks were randomly allotted to six dietary treatments (mEq/kg: 210, 240, 270, 300, 330, 360 DEB) with five replicate groups in a Completely Randomized Design (CRD). Feed grade Potassium chloride and Sodium bicarbonate, and the inherent potassium, sodium and chloride ions in feed ingredients were the electrolyte sources. The aggregate DEB was calculated using the equations derived by [14]. The derived equations were based on the following assumptions for an ideal DEB.

1) The DEB equation is dependent on mineral sources.

2) The DEB equation must be able to hold other macro ions at a constant, whose excess or deficiency could constitute an imbalance.

3) Other macro ions are held at a constant under recommended value ranges for broiler chickens.

The derived equation of DEB is

$$
\sum \mathrm{DEB}=\sum\left(\mathrm{Na}^{+}+\mathrm{K}^{+}\right)-\sum \mathrm{Cl}^{-} \cdots[\mathrm{y}][\mathrm{c}] .
$$

where $[y]=$ mineral sources.

And $[\mathrm{c}]=$ other macro ions $(\mathrm{Ca}, \mathrm{Mg}, \mathrm{P}, \mathrm{S}$ etc) held constant.

Aggregate DEB = Inherent DEB in rations + DEB in Electrolyte sources.

The concept of aggregate DEB postulated by [14] has shown that regardless of poultry feed ingredients compounded to make up a balanced ration, there exist in rations fed to broiler chickens, an inherent dietary electrolyte balance ranging from 115 to $210 \mathrm{mEq} / \mathrm{kg}$. Therefore, not more than 30 to 140 $\mathrm{mEq} / \mathrm{kg} \mathrm{DEB}$ are required from mineral sources. Drinking water was supplied to heat-stressed birds as described by [15]. Maximum and minimum average ambient temperature and relative humidity were monitored on a daily basis. At days 21 and 35, venous blood samples $(5 \mathrm{~mL})$ were collected by puncture of the wing vein (brachial vein) in two birds per replicate pen by using sterilized needles. Samples were identified and fractionated, with $2 \mathrm{~mL}$ put into a tube containing anticoagulant (EDTA) and $3 \mathrm{~mL}$ saved for other analyses. Samples containing anticoagulant were used to analyze haematological parameters and to calculate the heterophil to lymphocyte ratio. Haematological parameters measured includes packed cells volume (PCV), white blood cells (WBC), heterophils, eosinophils, basophils, lymphocytes, monocytes [16], haemoglobin $(\mathrm{Hb})$ concentrations (measured by Sahli's haemoglobinometer), and Red blood cells (RBC). The WBC was done in a haemocytometer chamber using Natt and Herric diluents [17] to obtain a 1:200 blood dilution. The PCV was measured as micro haematocrit with $75 \times 16 \mathrm{~mm}$ capillary tubes filled with blood and centrifuged at $2500 \mathrm{rpm}$ for $5 \mathrm{~min}$. The differential leukocyte counts were made on monolayer blood films prepared and fixed in absolute methanol for 2 to $5 \mathrm{~min}$ and were subsequently stained as described by [18] and examined under a light microscope. Blood glucose and some serum inorganic elements ( $\mathrm{Na}, \mathrm{K}, \mathrm{Cl}, \mathrm{Mg}$, and bicarbonates) and blood $\mathrm{pH}$ were also assessed. Assay was conducted in each diet for sodium and potassium (Flame spectrophotometer), and chloride (titration) [19]. Data obtained were subjected to descriptive statistics and analysis of variance using SAS package [20]. Means for treatments in the analysis of variance were compared using Duncan Multiple range test and all statement of significance were based on probability level of 0.05 .

\section{RESULTS AND DISCUSSION}

Table 1 shows the analysed nutrients in dietary treatments fed to broilers at starter and finisher phases under tropical conditions. The effect of varying electrolyte balance in feed on haematology and blood glucose of broiler chickens reared under high temperature-humidity index at starter phase is shown in Table 2. It was observed that haematological parameters and blood glucose were not significantly $(\mathrm{P}>$ 0.05) affected by varying dietary electrolyte balance in heat-stressed broiler chickens at starter phase. 
Table 1. Analysed nutrients in experimental diets fed to broiler chicks at starter and finisher phases.

\begin{tabular}{cccccccc}
\hline \multirow{2}{*}{ PERIODS } & NUTRIENTS (\%) & \multicolumn{7}{c}{ Diets $(\mathrm{mEq} / \mathbf{k g})$} & & \\
\cline { 3 - 7 } & Crude protein & 210 & 240 & 270 & 300 & 330 & 360 \\
\hline & Crude fat & 5.29 & 5.26 & 5.44 & 5.54 & 5.46 & 5.66 \\
& Calcium & 1.01 & 1.02 & 1.04 & 1.01 & 1.02 & 1.03 \\
$\mathbf{0}-\mathbf{2 1} \mathrm{d}$ & Phosphorus & 0.82 & 0.83 & 0.89 & 0.81 & 0.83 & 0.82 \\
& Sodium & 0.14 & 0.22 & 0.29 & 0.36 & 0.43 & 0.51 \\
& Potassium & 0.82 & 0.87 & 0.92 & 0.97 & 1.02 & 1.07 \\
& Chloride & 0.23 & 0.28 & 0.33 & 0.38 & 0.43 & 0.48 \\
& Crude protein & 21.78 & 21.67 & 21.84 & 21.79 & 21.66 & 21.85 \\
& Crude fat & 4.24 & 4.20 & 4.15 & 4.11 & 4.21 & 4.09 \\
& Calcium & 1.03 & 0.94 & 0.94 & 0.95 & 0.96 & 0.96 \\
& Phosphorus $-35 \mathrm{~d}$ & 0.78 & 0.77 & 0.78 & 0.78 & 0.78 & 0.78 \\
& Sodium & 0.16 & 0.23 & 0.29 & 0.37 & 0.44 & 0.52 \\
& Potassium & 0.83 & 0.85 & 0.89 & 0.95 & 0.99 & 1.04 \\
& Chloride & 0.25 & 0.27 & 0.32 & 0.37 & 0.42 & 0.47 \\
\hline
\end{tabular}

Table 2. Effect of varying dietary electrolyte balance on haematology and blood glucose of heatstressed broiler chickens at starter phase.

\begin{tabular}{ccccccccccccc}
\hline $\begin{array}{c}\mathrm{DEB} \\
\mathrm{mEq} / \mathrm{Kg}\end{array}$ & $\begin{array}{c}\mathrm{PCV} \\
(\%)\end{array}$ & $\begin{array}{c}\mathrm{Hb} \\
(\mathrm{g} / \mathrm{dL})\end{array}$ & $\begin{array}{c}\mathrm{RBC} \\
\left(10^{6} \mu \mathrm{l}\right)\end{array}$ & $\begin{array}{c}\text { WBC } \\
\left(10^{3} \mu \mathrm{l}\right)\end{array}$ & $\begin{array}{c}\text { Lymp } \\
(\%)\end{array}$ & $\begin{array}{c}\text { Hetero } \\
(\%)\end{array}$ & $\begin{array}{c}\text { Mono } \\
(\%)\end{array}$ & $\begin{array}{c}\text { Eos } \\
(\%)\end{array}$ & $\begin{array}{c}\text { Baso } \\
(\%)\end{array}$ & $\begin{array}{c}\text { Platelet } \\
\left(\times 10^{3}\right)\end{array}$ & $\begin{array}{c}\text { GLU } \\
(\mathrm{mg} / \mathrm{dL})\end{array}$ & $\begin{array}{c}\text { Hetero: } \\
\text { Lymp }\end{array}$ \\
\hline 210 & 32.40 & 10.50 & 3.31 & 21.78 & 59.80 & 32.80 & 2.80 & 4.00 & 0.40 & 24.20 & 235.03 & 0.60 \\
240 & 32.00 & 10.60 & 3.39 & 22.34 & 65.40 & 28.00 & 2.60 & 3.60 & 0.40 & 21.92 & 205.84 & 0.44 \\
270 & 31.20 & 10.30 & 3.27 & 22.85 & 64.20 & 28.60 & 3.00 & 5.00 & 0.20 & 26.50 & 207.21 & 0.45 \\
300 & 31.00 & 10.16 & 3.29 & 20.45 & 56.20 & 36.60 & 2.60 & 3.60 & 0.00 & 20.78 & 237.77 & 0.67 \\
330 & 31.80 & 10.48 & 3.40 & 20.70 & 57.80 & 35.40 & 3.00 & 3.40 & 0.40 & 20.82 & 219.01 & 0.66 \\
360 & 32.60 & 10.40 & 3.42 & 20.07 & 65.60 & 27.00 & 4.40 & 3.00 & 0.00 & 25.96 & 218.76 & 0.44 \\
SEM & 0.97 & 0.35 & 0.07 & 1.83 & 3.93 & 4.26 & 0.64 & 0.78 & 0.19 & 49.39 & 14.32 & 0.11 \\
P Value & 0.83 & 0.96 & 0.52 & 0.86 & 0.39 & 0.48 & 0.37 & 0.58 & 0.41 & 0.93 & 0.51 & 0.44 \\
\hline
\end{tabular}

PCV_Pack cell volume, Hb-Haemoglobin content, RBC-Red blood cell, WBC—white blood cell, Lymp-Lymphocyte, Hetero-Heterophil, Mono-Monocyte, Eos-Eosinophil, Baso-Basophil, GLUGlucose, SEM-Standard error of mean, P Value—probability, DEB-dietary electrolyte balance. 
However, a numerical increase was observed in heterophil to lymphocyte ratio of birds fed $300 \mathrm{mEq} / \mathrm{kg}$ $\mathrm{DEB}$ at day 21. However, at finisher phase (Table 3$)$, there were no significant $(\mathrm{P}>0.05)$ differences observed in PCV, Hb, RBC, WBC, monocyte, eosinophils, basophils, platelet and blood glucose, but lymphocyte and heterophils of heat-stressed birds fed varying DEB were significantly $(\mathrm{P}<0.05)$ affected at finisher phase. It was observed that birds fed $210 \mathrm{mEq} / \mathrm{kg}$ aggregate DEB had lower $(\mathrm{P}<0.05)$ lymphocyte count and did not differ $(\mathrm{P}>0.05)$ from 300, 330 and $360 \mathrm{mEq} / \mathrm{kg}$ DEB. The heterophils of birds fed 240 and $270 \mathrm{mEq} / \mathrm{kg}$ DEB were lower $(\mathrm{P}<0.05)$ compared to other dietary treatments. Birds on 240 and 270 $\mathrm{mEq} / \mathrm{kg} \mathrm{DEB}$ had significantly $(\mathrm{P}<0.05)$ lower heterophil to lymphocyte ratio compared to other DEB treatments. The results of present study corroborate the report of [7] and [8] who noted that during heat stress, there is increase in heterophilsand decrease in lymphocyte values along with an increase in $\mathrm{H}$ to $\mathrm{L}$ ratios. However, contradictory report was observed at finisher phase in present study with respect to [9] who noted higher blood glucose in heat stressed broiler chickens. [10] reported lower values of blood haematocrit in heat-stressed birds. The result of present findings was not consistent with the report of [7] who noted lower haemoglobin concentration in heat stressed broilers. This may be due to the fact that the concept of aggregate DEB inherent in feeds was not critically considered.

The effect of different DEB treatments on some serum inorganic elements and blood $\mathrm{pH}$ of heat-stressed broiler chickens at finisher phase is shown in Table 4. It was observed that there were no significant $(\mathrm{P}>0.05)$ differences in blood sodium, magnesium, bicarbonate and $\mathrm{pH}$ of heat-stressed birds on varying levels of aggregate DEB. However, blood potassium and chlorine ion in heat-stressed birds were affected by varying DEB at finisher phase. Birds on $330 \mathrm{mEq} / \mathrm{kg}$ aggregate DEB had higher $(\mathrm{P}<0.05)$ blood potassium concentration and a lower $(\mathrm{P}<0.05)$ chloride concentration, while birds fed $240 \mathrm{mEq} / \mathrm{kg}$ DEB had significantly $(\mathrm{P}<0.05)$ higher blood chloride concentration. These results partly agree with the findings of [21] who reported that there was no significant effect of dietary $\mathrm{Na}(0.20 \%, 0.25 \%$, and $0.30 \%)$, $\mathrm{Cl}(0.30 \%, 0.40 \%$, and $0.50 \%)$ or $\mathrm{Na}$ and $\mathrm{Cl}$ on blood $\mathrm{pH}$, serum $\mathrm{Na}$ and $\mathrm{K}$ contents at fixed $\mathrm{DEB}$ of 250 $\mathrm{mEq} / \mathrm{kg}$. Contrary to these, [22] reported that blood $\mathrm{Na}^{+}, \mathrm{K}^{+}$and $\mathrm{Cl}^{-}$levels were the direct impact of supplemented minerals. The authors noticed higher blood $\mathrm{Na}^{+}, \mathrm{K}^{+}$and $\mathrm{Cl}^{-}$levels in birds fed $\mathrm{Na}^{+}, \mathrm{K}^{+}$and

Table 3. Effect of varying dietary electrolyte balance on haematology and blood glucose of heatstressed broiler chickens at finisher phase.

\begin{tabular}{|c|c|c|c|c|c|c|c|c|c|c|c|c|}
\hline $\begin{array}{c}\mathrm{DEB} \\
\mathrm{mEq} / \mathrm{Kg}\end{array}$ & $\begin{array}{c}\text { PCV } \\
(\%)\end{array}$ & $\begin{array}{c}\mathrm{Hb} \\
(\mathrm{g} / \mathrm{dl})\end{array}$ & $\begin{array}{c}\text { RBC } \\
\left(10^{6} \mu \mathrm{l}\right)\end{array}$ & $\begin{array}{c}\text { WBC } \\
\left(10^{3} \mu \mathrm{l}\right)\end{array}$ & $\begin{array}{c}\text { Lymp } \\
(\%)\end{array}$ & $\begin{array}{c}\text { Hetero } \\
(\%)\end{array}$ & $\begin{array}{c}\text { Mono } \\
(\%)\end{array}$ & $\begin{array}{l}\text { Eos } \\
(\%)\end{array}$ & $\begin{array}{c}\text { Baso } \\
(\%)\end{array}$ & $\begin{array}{c}\text { Platelet } \\
\left(\times 10^{4}\right)\end{array}$ & $\begin{array}{c}\text { GLU } \\
(\mathrm{mg} / \mathrm{dl})\end{array}$ & $\begin{array}{c}\text { Hetero: } \\
\text { Lymp }\end{array}$ \\
\hline 210 & 27.40 & 8.76 & 2.75 & 23.40 & $60.40^{\mathrm{b}}$ & $32.00^{\mathrm{a}}$ & 4.00 & 4.20 & 0.00 & 22.84 & 209.86 & $0.55^{\mathrm{a}}$ \\
\hline 240 & 29.40 & 9.50 & 3.52 & 21.14 & $71.80^{\mathrm{a}}$ & $21.80^{\mathrm{c}}$ & 2.80 & 4.00 & 0.40 & 22.30 & 199.20 & $0.31^{\mathrm{c}}$ \\
\hline 270 & 30.00 & 9.64 & 3.01 & 21.70 & $69.00^{\mathrm{ab}}$ & $23.80^{\mathrm{bc}}$ & 2.60 & 4.60 & 0.00 & 21.60 & 182.78 & $0.35^{\mathrm{bc}}$ \\
\hline 300 & 30.60 & 9.80 & 3.11 & 18.79 & $61.20^{\mathrm{b}}$ & $31.80^{\mathrm{ab}}$ & 3.20 & 3.40 & 0.40 & 18.74 & 214.03 & $0.54^{\mathrm{ab}}$ \\
\hline 330 & 30.00 & 9.74 & 3.52 & 18.34 & $63.00^{\mathrm{b}}$ & $30.80^{\mathrm{ab}}$ & 2.40 & 3.60 & 0.20 & 66.30 & 216.42 & $0.49^{\mathrm{ab}}$ \\
\hline 360 & 28.80 & 10.00 & 3.26 & 27.74 & $61.00^{\mathrm{b}}$ & $31.80^{\mathrm{ab}}$ & 2.60 & 4.40 & 0.20 & 54.16 & 209.66 & $0.53^{\mathrm{ab}}$ \\
\hline SEM & 2.12 & 0.68 & 0.27 & 2.92 & 2.75 & 2.53 & 0.64 & 0.94 & 0.22 & 22.36 & 21.59 & 0.06 \\
\hline P Value & 0.91 & 0.84 & 0.32 & 0.26 & 0.03 & 0.02 & 0.53 & 0.93 & 0.67 & 0.54 & 0.89 & 0.03 \\
\hline
\end{tabular}

${ }^{\mathrm{abc}}$ Means for treatments within a column with no common superscript showed significant $(\mathrm{P}<0.05)$ differences using DMRT. PCV—Pack cell volume, Hb-Haemoglobin content, RBC—Red blood cell, WBCwhite blood cell, Lymp-Lymphocyte, Hetero-Heterophil, Mono-Monocyte, Eos-Eosinophils, BasoBasophils, GLU-Glucose, SEM-Standard error of mean, P Value-probability. 
Table 4. Effect of varying dietary electrolyte balance on some serum inorganic elements and blood $\mathrm{pH}$ of broiler chickens at finisher phase.

\begin{tabular}{ccccccc}
\hline DEB mEq/kg & $\begin{array}{c}\text { Sodium } \\
(\mathrm{mmol} / \mathrm{l})\end{array}$ & $\begin{array}{c}\text { Potassium } \\
(\mathrm{mmol} / \mathrm{l})\end{array}$ & $\begin{array}{c}\text { Chloride } \\
(\mathrm{mmol} / \mathrm{l})\end{array}$ & $\begin{array}{c}\text { Magnesium } \\
(\mathrm{mmol} / \mathrm{l})\end{array}$ & $\begin{array}{c}\text { Bicarbonate } \\
(\mathrm{mmol} / \mathrm{l})\end{array}$ & $\begin{array}{c}\text { Blood } \\
\mathrm{pH}\end{array}$ \\
\hline 210 & 133.68 & $2.07^{\mathrm{b}}$ & $116.45^{\mathrm{ab}}$ & 1.98 & 23.03 & 9.50 \\
240 & 131.07 & $1.79^{\mathrm{b}}$ & $136.95^{\mathrm{a}}$ & 2.15 & 21.44 & 9.68 \\
270 & 135.78 & $1.93^{\mathrm{b}}$ & $113.80^{\mathrm{ab}}$ & 2.03 & 22.62 & 9.44 \\
300 & 129.47 & $2.15^{\mathrm{b}}$ & $119.79^{\mathrm{ab}}$ & 2.08 & 20.96 & 9.42 \\
330 & 133.42 & $2.96^{\mathrm{a}}$ & $131.16^{\mathrm{ab}}$ & 2.14 & 20.31 & 9.48 \\
360 & 130.53 & $1.91^{\mathrm{b}}$ & $109.52^{\mathrm{b}}$ & 2.04 & 20.18 & 9.54 \\
SEM & 11.16 & 0.26 & 7.82 & 0.09 & 0.95 & 0.12 \\
P Value & 0.99 & 0.04 & 0.14 & 0.72 & 0.21 & 0.69 \\
\hline
\end{tabular}

${ }^{a b}$ Means for treatments within a column with no common superscript showed significant $(\mathrm{P}<0.05)$ differences using DMRT. SEM-Standard error of mean, P Value-probability, DEB-dietary electrolyte balance.

$\mathrm{Cl}^{-}$supplements, respectively. [23] noted that potassium level in the body correlates with muscle mass and it used to calculate the body mass in vivo application of radioactive isotope of potassium-K40. [12] reported that as ambient temperature rises, the blood potassium ion and sodium ion concentration decreases, while chloride ion increases leading to low blood electrolyte balance. However, [13] did not observed any significant effect of varying DEB treatments on blood electrolytes, blood glucose and physiological parameters in heat stressed broilers. The authors opined that during heat stress, broiler chickens made use of compensatory mechanisms when attempting to maintain acid-base homeostasis, blood nutrient and physiological variable concentrations. One of such includes the intake of water that aids digestion process and adsorption of nutrients needed to maintain balance as reported by [15]. [24] reported that for every $0.25 \%$ increase in sodium chloride content of the diet there will be an additional $9 \mathrm{~g}$ excretion of water per gram of faeces.

\section{IMPLICATION}

Heterophil to lymphocyte ratio of heat-stressed broilers was significantly lower at a dietary electrolyte balance of 240 and $270 \mathrm{mEq} / \mathrm{kg}$ during finisher phase indicating an ameliorating effect on heat stress. However, blood acid-base balance was relatively enhanced in birds on DEB level of $360 \mathrm{mEq} / \mathrm{kg}$ with reduced chloride ion and relatively lower incidence of hemodilution with respect to high haemoglobin levels. Therefore, an aggregate dietary electrolyte balance of $360 \mathrm{mEq} / \mathrm{kg}$ is advantageous in balancing blood acid to base ratio in broiler chickens reared under severe environmental temperatures higher than $43^{\circ} \mathrm{C} \pm 5^{\circ} \mathrm{C}$ as against some previous opinions that did not take into consideration, the inherent dietary electrolyte balance in feedstuff, other functional mono or divalent ions, and the severity of environmental factors.

\section{ACKNOWLEDGEMENTS}

The profound moral and financial supports of Engr. and Mrs Popoola are hereby acknowledged.

\section{CONFLICTS OF INTEREST}

The authors declare no conflicts of interest as regarding the publication of this paper. 


\section{REFERENCES}

1. Belay, T. and Teeter, R.G. (1993) Broiler Water Balance and Thermobalance during Thermoneutral and High Ambient Temperature Exposure. Poultry Science, 72, 116-124. https://doi.org/10.3382/ps.0720116

2. Borges, S.A., Fischer Da Silva, A.V., Ariki, J., Hooge, D.M. and Cummings, K.R. (2003) Dietary Electrolyte Balance for Broiler Chickens under Moderately High Ambient Temperatures and Relative Humidities. Poultry Science, 82, 301-308. https://doi.org/10.1093/ps/82.2.301

3. Ahmad, T., Mahr-un-nisa, Mushtaq, T., Mirza, M.A., Hooge, D.M. and Sarwar, M. (2006) Effect of Different Non-Chloride Sodium Sources on the Performance of Heat Stressed Broiler Chickens. British Poultry Science, 47, 1-8. https://doi.org/10.1080/00071660600753342

4. Benton, C.E., Balnave, D. and Brake, J. (1998) The Use of Dietary Minerals during Heat Stress in Broilers: Review. The Professional Animal Scientist, 14, 193-196. https://doi.org/10.15232/S1080-7446(15)31828-3

5. Ruiz-Lopez, B. and Austic, R.E. (1993) The Effects of Selected Minerals on Acid-Base Balance of Growing Chicks. Poultry Science, 72, 1054-1062. https://doi.org/10.3382/ps.0721054

6. Maxwell, M.H. and Robertson, G.W. (1998) The Avian Heterophil Leukocyte: A Review. World s Poultry Science Journal 54, 155-178. https://doi.org/10.1079/WPS19980012

7. Bedanova, I., Voslarova, E., Vecerek, V., Strakova, E. and Suchy, P. (2003) The Haematological Profile of Broilers under Acute and Chronic Heat Stress at $30 \pm 1{ }^{\circ} \mathrm{C}$ Level. Folia Veterinaria 47, 188-192.

8. Borges, S.A., Fischer Da Silva, A.V., Maiorka, A., Hooge, D.M. and Cummings, K.R. (2004) Effects of Diet and Cyclic Daily Heat Stress on Electrolyte, Nitrogen and Water Intake, Excretion and Retention by Colostomized Male Broiler Chickens. International Journal of Poultry Science, 3, 313-321.

https://doi.org/10.3923/ijps.2004.313.321

9. Borges, S.A. (2001) Balanco eletrolitico e sua interrelacao com o equilibrio acidobase em frangos de corte submetidos a estresse calorico. Jaboticabal. Tese (Doutorado em Zootecnia) curso de posgraduacao em Zootecnia, Universidade Estadual Paulista, 97.

10. Zhou, W.T., Fujita, M. and Yamamoto, S. (1999) Thermoregulatory Responses and Blood Viscosity in Dehydrated Heat Exposed Broilers (Gallus domesticus). Journal of Thermal Biology, 24, 185-192.

https://doi.org/10.1016/S0306-4565(99)00010-8

11. Vecerek, V., Strakova, E., Suchy, P. and Voslarova, E. (2002) Influence of High Environmental Temperature on Production and Haematological and Biochemical Indexes in Broiler Chickens. Czech Journal of Animal Science, 47, 176-182.

12. Borges, S.A., Fischer Da Silva, A.V., Majorka, A., Hooge, D.M. and Cummings, K.R. (2004) Physiological Responses of Broiler Chickens to Heat Stress and Dietary Electrolyte Balance (Sodium plus Potassium minus Chloride, Milliequivalent per Kilogram). Poultry Science, 83, 1551-1558. https://doi.org/10.1093/ps/83.9.1551

13. Borges, S.A., Fischer Da Silva, A.V., Ariki, J., Hooge, D.M. and Cummings, K.R. (2003b) Dietary Electrolyte Balance for Broiler Chickens Exposed to Thermoneutral or Heat-Stress Environments. Poultry Science, 82, 428-435. https://doi.org/10.1093/ps/82.3.428

14. Popoola, I.O. and Iyayi, E.A. (2018) Response of Heat-Stressed Broiler Chicks to Varying Dietary Electrolyte Balance at Pre-Starter and Starter Phases. 43rd Annual Conference of the Nigerian Society for Animal Production, Owerri, 18-22 March 2018.

15. Popoola, I.O., Oshibanjo, D.O., Popoola, O.R., Okuneye, T.A., Ilaboya, I.I. and Iyayi, E.A. (2019) Effect of Dietary Electrolyte Balance on Water Intake, Litter Moisture and Production of Broiler Chicks at Pre-Starter and Starter Phases. Open Journal of Animal Sciences, 9, 472-480. https://doi.org/10.4236/ojas.2019.94036

16. Dein, F.J. (1984) Laboratory Manual of Avian Haematology. Association of Avian Veterinarian, East North 
Port.

17. Natt, P.M. and Herrik, C.A. (1952) A New Blood Diluent for Counting the Erythrocytes and Leucocytes of Chicken. Poultry Science, 31, 735-738. https://doi.org/10.3382/ps.0310735

18. Dacie, J.U. and Lewis, S.M. (1975) Practical Haematology. Churchill Livingstone, London.

19. Lacroix, R.L., Keeney, D.R. and Welsh, L.M. (1970) Potentiometric Titration of Chloride in Plant Tissue Extracts Using the Chloride Ion Electrode. Communications in Soil Science and Plant Analysis, 1, 1-6.

https://doi.org/10.1080/00103627009366233

20. Statistical Analysis System (2012) SAS Users Guide: Statistics. SAS Institute Inc., Cary.

21. Mushtaq, T., Sarwar, M., Nawaz, H., Mirza, M.A. and Ahmad, T. (2005) Effect and Interactions of Sodium and Chloride on Broiler Starter Performance (One-to-Twenty-Eight Days) under Subtropical Summer Condition. Poultry Science, 84, 1716-1722. https://doi.org/10.1093/ps/84.11.1716

22. Ahmad, T., Sarwar, M., Mahr-un-nisa, Ahsan-ul-haq and Zia-ul-hasan (2005) Influence of Varying Sources of Dietary Electrolytes on the Performance of Broilers Reared in a High Temperature Environment. Animal Feed Science and Technology, 20, 277-298. https://doi.org/10.1016/j.anifeedsci.2005.02.028

23. Jovanović, R., Dujić, D. and Glamočić, D. (2001) Ishrana domaćih životinja, 2. izmenjeno i dopunjeno izdanje, Stylos-Izdavaštvo, Novi Sad.

24. Smith, A.S., Rose, R.G. and Wells, P.V. (2000) Effect of Excess Dietary Sodium, Potassium, Calcium, and Phosphorus on Excreta Moisture of Laying Hens. British Poultry Science, 41, 598-607.

https://doi.org/10.1080/713654976 